\title{
Algoriphagus faecimaris sp. nov., isolated from coastal sediment
}

\author{
Yongxia Li, ${ }^{1}$ Shulin Yan, ${ }^{1}$ Qian Yang, ${ }^{1}$ Zizhong $\mathrm{Qi},{ }^{2}$ Xiao-Hua Zhang ${ }^{1}$ \\ and $\mathrm{Yu}$-Bin $\mathrm{Fu}^{3}$ \\ ${ }^{1}$ Department of Marine Biology, Ocean University of China, Qingdao, PR China \\ ${ }^{2}$ Key Laboratory of Marine Genetics and Breeding (Ocean University of China), Ministry of \\ Education, Qingdao, PR China \\ ${ }^{3}$ Institute of Material Science and Engineering, Ocean University of China, Qingdao, PR China
}

Correspondence

Zizhong Qi

zizhongqi@ouc.edu.cn

Xiao-Hua Zhang

xhzhang@ouc.edu.cn
A Gram-negative, non-motile, non-sporulating bacterial strain, designated $\mathrm{LYX}^{\top}{ }^{\top}$, was isolated from coastal sediment of Qingdao, China, on the coast of the Yellow Sea. Strain LYX05 ${ }^{\top}$ was aerobic and heterotrophic. The strain grew optimally at $37{ }^{\circ} \mathrm{C}$ and pH 7.5 and in the presence of $2 \%(\mathrm{w} / \mathrm{v}) \mathrm{NaCl}$. Colonies were $1-2 \mathrm{~mm}$ in diameter, circular, reddish orange and shiny with entire edges on marine agar medium. Cells were rods (0.3-0.5 $\mu \mathrm{m}$ wide and 0.8-1.6 $\mu \mathrm{m}$ long). The dominant fatty acids were iso- $C_{15: 0}(40.82 \%)$ and $C_{16: 0}(10.45 \%)$. The DNA $G+C$ content was $42.5 \mathrm{~mol} \%$. Phylogenetic analysis based on $16 \mathrm{~S}$ rRNA gene sequences indicated that strain LYX05 ${ }^{\top}$ was phylogenetically related to the members of the genus Algoriphagus and the closest relative was Algoriphagus hitonicola 7-UAH ${ }^{\top}$ (95.8\% 16S rRNA gene sequence similarity). On the basis of phenotypic, chemotaxonomic and phylogenetic data, strain $\mathrm{LYXO5}^{\top}$ was considered to represent a novel species of the genus Algoriphagus, for which the name Algoriphagus faecimaris sp. nov. is proposed. The type strain is $\mathrm{LYXO5}^{\top}\left(=\mathrm{JCM} 16561^{\top}=\mathrm{DSM} 23095^{\top}=\mathrm{LMG}\right.$ $25474^{\top}$ ).
The genus Algoriphagus was proposed by Bowman et al. (2003) for heterotrophic, Gram-negative, non-motile, strictly aerobic, pink-pigmented, rod-like, cold-adapted strains, at which time the genus was represented by a single species, Algoriphagus ratkowskyi. Phylogenetically, the genus is distantly related to the genus Cyclobacterium within the phylum Bacteroidetes. On the basis of phylogenetic, phenotypic and genotypic evidence, the members of the genera Chimaereicella and Hongiella, Chimaereicella alkaliphila (Tiago et al., 2006), C. boritolerans (Ahmed et al., 2007), Hongiella marincola (Yoon et al., 2004), H. mannitolivorans, $H$. ornithinivorans and H. halophilus (Yi \& Chun, 2004), were reclassified into the genus Algoriphagus (Nedashkovskaya et al., 2004, 2007). Currently, the genus Algoriphagus contains 19 species. The majority of these were isolated from marine environments or saline lakes (Copa-Patiño et al., 2008; Park et al., 2010; Van Trappen et al., 2004); Algoriphagus terrigena was discovered in a soil sample (Yoon et al., 2006), Algoriphagus aquatilis was isolated from freshwater (Liu et al., 2009) and Algoriphagus olei was recovered from an oilcontaminated soil near an oil refinery (Young et al., 2009). In

The GenBank/EMBL/DDBJ accession number for the 16S rRNA gene sequence of strain $\mathrm{LYXO5}^{\top}$ is GU072591.

Two supplementary figures and a supplementary table are available with the online version of this paper. this study, we report the taxonomic characterization of an Algoriphagus-like bacterial strain, LYX05 ${ }^{\mathrm{T}}$, which was isolated from coastal sediment of Jiaozhou Bay, near the estuary of the river Lichun at Qingdao, China, on the coast of the Yellow Sea $\left(36^{\circ} 09^{\prime} \mathrm{N} 120^{\circ} 21^{\prime} \mathrm{E}\right)$.

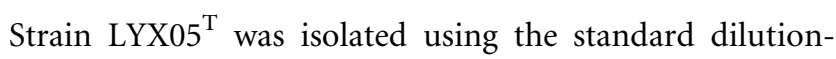
plating technique on marine agar 2216 (MA; Difco) after incubation at $28{ }^{\circ} \mathrm{C}$ for 2 days. The morphological, physiological and biochemical characteristics of strain LYX $05^{\mathrm{T}}$ were investigated together with two reference strains, the environmentally similar Algoriphagus marincola DSM $16067^{\mathrm{T}}$ and A. ratkowskyi LMG $21435^{\mathrm{T}}$, which were obtained from the DSMZ and the BCCM, respectively. The isolate and the reference strains were routinely cultivated on $\mathrm{MA}$ at 37,28 and $16{ }^{\circ} \mathrm{C}$, respectively. Cell morphology and the presence of flagella were determined using transmission electron microscopy (JEM-1200EX; JEOL) with cells grown on MA at $37^{\circ} \mathrm{C}$ for $16 \mathrm{~h}$. The Gram reaction, catalase and oxidase activities, absorption maxima of crude extracts and hydrolysis of casein, gelatin, starch and Tweens 20, 40 and 80 were determined as described by Tindall et al. (2007). The presence of flexirubin-like pigments was tested according to Reichenbach (1989). Growth in the absence of $\mathrm{NaCl}$ was examined in trypticase soy broth (Difco) prepared without $\mathrm{NaCl}$. Growth with $1-10 \%(\mathrm{w} / \mathrm{v}) \mathrm{NaCl}$ (in increments of $1 \%$ ) was investigated in marine broth 2216 (MB; Difco). 
Growth at $\mathrm{pH} 3.5-10$ (in increments of $0.5 \mathrm{pH}$ units) was determined in $\mathrm{MB}$ with the $\mathrm{pH}$ adjusted using the appropriate biological buffers. Growth was measured by monitoring $\mathrm{OD}_{600}$ for 3 days. Growth at $0,4,16,28,37,42$ and $45{ }^{\circ} \mathrm{C}$ was measured on MA. Growth under anaerobic conditions was determined by incubation on MA in an enclosed cylinder with $10 \mathrm{~g}$ gallic acid and $100 \mathrm{ml} 10 \%$ $\left(\right.$ w/v) $\mathrm{NaOH}$ to absorb oxygen at $28{ }^{\circ} \mathrm{C}$ for 5 days.

Carbon-source assimilation was determined using GN MicroPlates (Biolog). Acid production from different carbohydrates was determined using API $50 \mathrm{CH}$ test strips and $50 \mathrm{CHB} / \mathrm{E}$ medium (bioMérieux) according to the manufacturer's instructions except that sterile 1.5-2\% $(\mathrm{w} / \mathrm{v}) \mathrm{NaCl}$ was used to prepare the inocula. Additional biochemical assays and enzyme activities were detected with the API 20 E, API $20 \mathrm{NE}$ and API ZYM systems (bioMérieux), according to the manufacturer's instructions except that sterile $1.5 \%(\mathrm{w} / \mathrm{v}) \mathrm{NaCl}$ was used to prepare the inocula. Susceptibility to antibiotics was determined on MA using filter-paper discs containing various antibiotics.

The DNA G + C content was determined by the method of Mesbah \& Whitman (1989). For isoprenoid quinone analysis, cell mass of strain LYX05 ${ }^{\mathrm{T}}$ and A. marincola DSM $16067^{\mathrm{T}}$ was obtained from cultures prepared in $\mathrm{MB}$ at $28{ }^{\circ} \mathrm{C}$. Analysis of fatty acid methyl esters of strain LYX $05^{\mathrm{T}}, A$. marincola DSM $16067^{\mathrm{T}}$ and A. ratkowskyi LMG $21435^{\mathrm{T}}$ was carried out according to the standard protocol of the Sherlock Microbial Identification System (Microbial ID) (Xie \& Yokota, 2003) with cells cultured in $\mathrm{MB}$ at $28{ }^{\circ} \mathrm{C}$ for 4 days.

The phylogenetic position of strain $\mathrm{LYX} 05^{\mathrm{T}}$ was determined by $16 \mathrm{~S}$ rRNA gene sequence analysis. Genomic DNA was prepared according to the protocol of Niemann et al. (1997). The 16S rRNA gene sequence was amplified using oligonucleotide primers complementary to highly conserved regions of bacterial $16 \mathrm{~S}$ rRNA genes. The forward primer was 27F (5'-AGAGTTTGATCCTGGCTCAG-3') and the reverse primer was 1492R ( $5^{\prime}$-GGTTACCTTGTTACGACTT-3'). Sequences were initially analysed using BLAST (http://www.ncbi.nlm.nih.gov; http://www.eztaxon. org/; Chun et al., 2007) and, from these search results, selected sequences were collected manually. After multiple alignment using CLUSTAL X (Thompson et al., 1997), phylogenetic trees were reconstructed with the neighbourjoining and maximum-parsimony methods using MEGA version 4 (Tamura et al., 2007), according to the default settings.

The morphological, physiological and biochemical characteristics of strain $\mathrm{LYX}_{0} 5^{\mathrm{T}}$ are shown in Table 1, the species description and Supplementary Fig. S1 (available in IJSEM Online). The phenotypic properties of strain LYX $05^{\mathrm{T}}$ were in agreement with those given for the genus Algoriphagus (Bowman et al., 2003), such as the absence of motility, the marine habitat and the production of nondiffusible pink and red pigments. However, cell extracts of strain $\mathrm{LYX}^{\mathrm{T}}{ }^{\mathrm{T}}$ showed an absorption peak maximum at $482 \mathrm{~nm}$, no acid production from amygdalin, salicin or melezitose and utilization of D-fructose, lactose, maltose and D-mannose. These and other characters differentiated strain $\mathrm{LYX}^{\mathrm{T}}{ }^{\mathrm{T}}$ from its closest phylogenetic neighbours (Table 1).

An almost-complete 16S rRNA gene sequence of strain LYX05 ${ }^{\mathrm{T}}$, comprising $1397 \mathrm{nt}$, was determined. In the neighbour-joining phylogenetic tree, strain $\mathrm{LYX} 5^{\mathrm{T}}$ fell within the cluster comprising the genus Algoriphagus and clustered closely with A. marincola SW-2 ${ }^{\mathrm{T}}$ (Fig. 1). A similar topology was found with the maximum-parsimony algorithm (Supplementary Fig. S2). Strain LYX05 ${ }^{\mathrm{T}}$ exhibited $92.7-95.8 \% 16 \mathrm{~S}$ rRNA gene sequence similarity with the type strains of the 19 species of the genus Algoriphagus. The isolate was most closely related to A. hitonicola 7 $\mathrm{UAH}^{\mathrm{T}}$ (95.8 \% 16S rRNA gene sequence similarity) and $A$. marincola SW $-2^{\mathrm{T}}(95.1 \%)$.

The predominant isoprenoid quinone detected in strain LYX $05^{\mathrm{T}}$ was menaquinone-7 (MK-7) and the dominant fatty acid was iso- $\mathrm{C}_{15: 0}$ (40.82\%; Supplementary Table S1), as described for the genus Algoriphagus (Nedashkovskaya et al.,

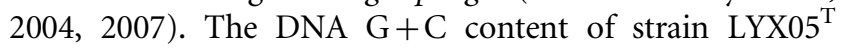
was $42.5 \mathrm{~mol} \%$, which is similar to values described for A. marincola ( $43.0 \mathrm{~mol} \%)$ and A. hitonicola (43.4 mol\%; Table 1).

On the basis of phylogenetic, phenotypic and chemotaxonomic evidence, strain LYX $05^{\mathrm{T}}$ represents a novel species of the genus Algoriphagus, for which the name Algoriphagus faecimaris sp. nov. is proposed.

\section{Description of Algoriphagus faecimaris sp. nov.}

Algoriphagus faecimaris (fa.e.ci.ma'ris. L. n. faex, faecis sediment; L. n. mare, -is the sea; N.L. gen. n. faecimaris of a sediment of the sea).

Cells are Gram-negative, non-sporulating, non-flagellated, strictly aerobic rods, $0.3-0.5 \mu \mathrm{m}$ wide and $0.8-1.6 \mu \mathrm{m}$ long. Colonies are 1-2 $\mathrm{mm}$ in diameter, circular, reddish orange and shiny with entire edges after 2 days on MA medium at $37{ }^{\circ} \mathrm{C}$. Grows at $0-42{ }^{\circ} \mathrm{C}$ (optimum $37^{\circ} \mathrm{C}$ ), at $\mathrm{pH} 6-12.5$ (optimum $\mathrm{pH} 7.5$ ) and with $0-8 \%$ (w/v) $\mathrm{NaCl}$ (optimum $2 \% \mathrm{NaCl}$ ). Nitrate is reduced to nitrite. Positive for oxidase and hydrolysis of aesculin and weakly positive for catalase, but negative for arginine dihydrolase and urease. Indole and hydrogen sulfide are not produced. Flexirubin-type pigments are not formed. Degrades gelatin, starch and Tween 20, degrades Tweens 40 and 80 weakly and does not degrade agar or casein. Acid is produced from D-galactose, D-glucose, D-fructose, aesculin, maltose, methyl $\alpha$-D-glucopyranoside, cellobiose, melibiose, sucrose, turanose and potassium 5ketogluconate, but not from amygdalin, glycerol, erythritol, salicin, melezitose, methyl $\alpha$-D-mannopyranoside, $N$-acetylglucosamine, inulin or potassium 2-ketogluconate. With API ZYM, positive for alkaline phosphatase, esterase (C4), esterase lipase (C8), leucine arylamidase, valine arylamidase, naphthol-AS-BI-phosphohydrolase, $N$-acetyl- $\beta$-glucosaminidase and acid phosphatase, weakly positive for cystine 
Table 1. Phenotypic characteristics of strain $\mathrm{LYXO5}^{\top}$ and its closest phylogenetic neighbours in the genus Algoriphagus

Strains: 1, Algoriphagus faecimaris sp. nov. LYX05 ${ }^{\mathrm{T}} ; 2$, A. marincola DSM 16067 ${ }^{\mathrm{T}}$; 3, A. ratkowskyi LMG 21435 ${ }^{\mathrm{T}}$; 4, A. hitonicola 7-UAH ${ }^{\mathrm{T}} ; 5$, A. ornithinivorans $\mathrm{JC} 2052^{\mathrm{T}} ; 6$, A. vanfongensis $\mathrm{KMM} 6241^{\mathrm{T}}$. Data in parentheses in columns 2 and 3 and all data in columns 4-6 were taken from Yoon et al. (2004), Bowman et al. (2003), Copa-Patiño et al. (2008), Yi \& Chun (2004) and Nedashkovskaya et al. (2007); other data were from this study. All strains are positive for aerobic metabolism, catalase, alkaline phosphatase and acid production from D-glucose. All strains are negative for gliding motility, production of flexirubin-type pigments, $\mathrm{H}_{2} \mathrm{~S}$ and indole production, urease and acid production from glycerol. + , Positive; w, weakly positive; $\mathrm{v}$, variable; -, negative; ND, no data available.

\begin{tabular}{|c|c|c|c|c|c|c|}
\hline Characteristic & 1 & 2 & 3 & 4 & 5 & 6 \\
\hline Pigment absorption maximum (nm) & 482 & 486 & $\mathrm{ND}$ & 481 & 480 & $\mathrm{ND}$ \\
\hline Nitrate reduction & + & - & - & + & - & - \\
\hline $\mathrm{NaCl}$ concentration for growth (\%) & $0-8$ & $1-9$ & $0-6$ & $1.5-5$ & $0-10$ & $0-8$ \\
\hline Growth temperature $\left({ }^{\circ} \mathrm{C}\right)$ & $0-42$ & $16-45(10-45)$ & $0-28(-2$ to 25$)$ & $20-40$ & $10-40$ & $12-35$ \\
\hline \multicolumn{7}{|l|}{ Hydrolysis of: } \\
\hline Casein & - & + & + & ND & - & - \\
\hline DNA & + & + & - & + & + & - \\
\hline Gelatin & + & - & - & ND & + & + \\
\hline Starch & + & + & $-(\mathrm{v})$ & + & + & - \\
\hline Tween 40 & $\mathrm{~W}$ & + & + & ND & + & - \\
\hline Tween 80 & $\mathrm{w}$ & + & - & - & + & - \\
\hline \multicolumn{7}{|l|}{ Acid production from: } \\
\hline Amygdalin & - & + & + & + & ND & ND \\
\hline D-Fructose & + & + & $\mathrm{w}$ & + & - & - \\
\hline D-Galactose & + & + & $\mathrm{W}$ & $\mathrm{ND}$ & - & - \\
\hline D-Lyxose & - & - & + & $\mathrm{ND}$ & $\mathrm{ND}$ & ND \\
\hline D-Mannitol & - & - & + & ND & - & ND \\
\hline D-Mannose & $\mathrm{w}$ & + & + & + & - & + \\
\hline Melezitose & - & + & + & ND & ND & ND \\
\hline Salicin & - & + & + & + & ND & ND \\
\hline D-Xylose & - & + & + & - & - & + \\
\hline $\mathrm{N}$-Acetylglucosamine & - & + & + & + & - & + \\
\hline \multicolumn{7}{|l|}{ Utilization of: } \\
\hline L-Arabinose & - & + & + & ND & - & + \\
\hline D-Galactose & - & + & + & ND & - & $\mathrm{ND}$ \\
\hline myo-Inositol & + & - & + & ND & - & - \\
\hline D-Mannitol & - & - & + & - & - & - \\
\hline D-Sorbitol & - & - & + & $\mathrm{ND}$ & - & - \\
\hline$N$-Acetyl-D-glucosamine & + & - & + & ND & + & + \\
\hline \multicolumn{7}{|l|}{ Susceptibility to: } \\
\hline Ampicillin & - & + & - & ND & + & - \\
\hline Doxycycline & - & - & $-(+)$ & ND & + & + \\
\hline Gentamicin & - & - & - & ND & - & + \\
\hline Kanamycin & - & - & - & - & + & - \\
\hline Neomycin & - & - & - & - & - & + \\
\hline Tetracycline & - & + & + & ND & + & + \\
\hline DNA G $+\mathrm{C}$ content $(\mathrm{mol} \%)$ & 42.5 & $(43)$ & $(35)$ & 43.4 & 38 & 43.8 \\
\hline
\end{tabular}

arylamidase and $\beta$-glucosidase and negative for lipase (C14), trypsin, $\alpha$-chymotrypsin, $\alpha$ - and $\beta$-galactosidase, $\alpha$-glucosidase, $\beta$-glucuronidase, $\beta$-mannosidase and $\alpha$-fucosidase. Sensitive to ( $\mu$ g per disc, unless indicated otherwise) ciprofloxacin (5), vancomycin (30), cefobid (75), cephalothin V (30), piperacillin (100) and chloromycetin (30); resistant to norfloxacin (10), polymyxin B (300 U), compound sulfamethoxazole (75), furazolidone (300), clindamycin (2), rocephin (30), amikacin (30), gentamicin (10), kanamycin (30), neomycin (30), tetracycline (30), doxycycline (30), minocycline (30), erythromycin (15), oxacillin sodium (1), ampicillin (10), cephalothin IV (30), cephalothin VI (30), cefuroxime (30), ceftazidime (30) and midecamycin (30). The dominant fatty acids are iso- $\mathrm{C}_{15: 0}$ and $\mathrm{C}_{16: 0}$. The DNA $\mathrm{G}+\mathrm{C}$ content of the type strain is $42.5 \mathrm{~mol} \%$.

The type strain is $\mathrm{LYX}_{0} 5^{\mathrm{T}}\left(=\mathrm{JCM} 16561^{\mathrm{T}}=\mathrm{DSM} 23095^{\mathrm{T}}\right.$ $=$ LMG $25474^{\mathrm{T}}$ ), which was isolated from coastal sediment of Jiaozhou Bay, near the estuary of the river Lichun at Qingdao, on the Yellow Sea coast of China. 


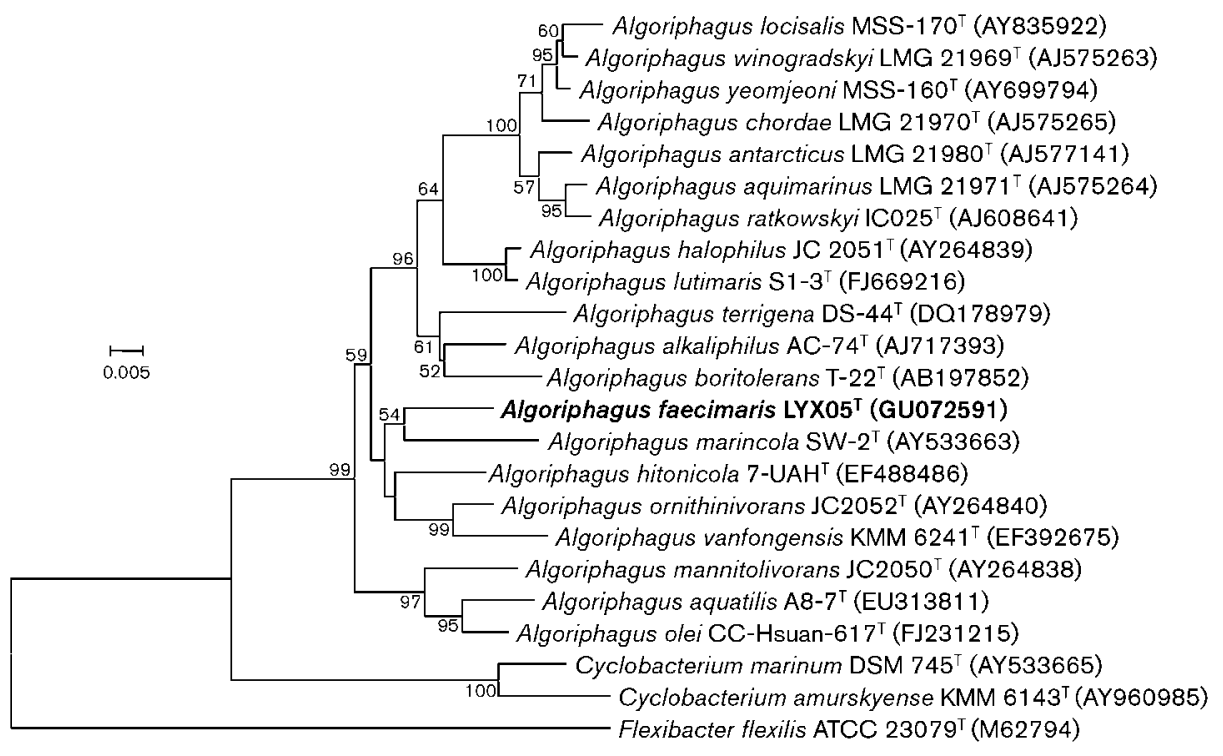

Fig. 1. Neighbour-joining phylogenetic tree based on 16S rRNA gene sequences showing the relationships between strain $\mathrm{LYX05}^{\mathrm{T}}$ and members of the genus Algoriphagus. Bootstrap values ( $\left.>50 \%\right)$ based on 1000 replications are shown at branch nodes. The sequence of Flexibacter flexilis ATCC $23079^{\top}$ was used as an outgroup. Bar, 0.005 nucleotide substitutions per position.

\section{Acknowledgements}

This work was supported by the Development Project Programs of Shandong (grant no. 2008GG10007003) and the National High Technology R\&D Program of China (grant no. 2007AA09Z434).

\section{References}

Ahmed, I., Yokota, A. \& Fujiwara, T. (2007). Chimaereicella boritolerans sp. nov., a boron-tolerant and alkaliphilic bacterium of the family Flavobacteriaceae isolated from soil. Int $J$ Syst Evol Microbiol 57, 986-992.

Bowman, J. P., Nichols, C. M. \& Gibson, J. A. (2003). Algoriphagus ratkowskyi gen. nov., sp. nov., Brumimicrobium glaciale gen. nov., sp. nov., Cryomorpha ignava gen. nov., sp. nov. and Crocinitomix catalasitica gen. nov., sp. nov., novel flavobacteria isolated from various polar habitats. Int J Syst Evol Microbiol 53, 1343-1355.

Chun, J., Lee, J.-H., Jung, Y., Kim, M., Kim, S., Kim, B. K. \& Lim, Y.-W. (2007). EzTaxon: a web-based tool for the identification of prokaryotes based on $16 \mathrm{~S}$ ribosomal RNA gene sequences. Int J Syst Evol Microbiol 57, 2259-2261.

Copa-Patiño, J. L., Arenas, M., Soliveri, J., Sánchez-Porro, C. \& Ventosa, A. (2008). Algoriphagus hitonicola sp. nov., isolated from an athalassohaline lagoon. Int J Syst Evol Microbiol 58, 424-428.

Liu, Y., Li, H., Jiang, J.-T., Liu, Y.-H., Song, X.-F., Xu, C.-J. \& Liu, Z.-P. (2009). Algoriphagus aquatilis sp. nov., isolated from a freshwater lake. Int J Syst Evol Microbiol 59, 1759-1763.

Mesbah, M. \& Whitman, W. B. (1989). Measurement of deoxyguanosine/thymidine ratios in complex mixtures by high-performance liquid chromatography for determination of the mole percentage guanine + cytosine of DNA. J Chromatogr A 479, 297-306.

Nedashkovskaya, O. I., Vancanneyt, M., Van Trappen, S., Vandemeulebroecke, K., Lysenko, A. M., Rohde, M., Falsen, E., Frolova, G. M., Mikhailov, V. V. \& Swings, J. (2004). Description of
Algoriphagus aquimarinus sp. nov., Algoriphagus chordae sp. nov. and Algoriphagus winogradskyi sp. nov., from sea water and algae, transfer of Hongiella halophila Yi and Chun 2004 to the genus Algoriphagus as Algoriphagus halophilus comb. nov. and emended descriptions of the genera Algoriphagus Bowman et al. 2003 and Hongiella Yi and Chun 2004. Int J Syst Evol Microbiol 54, 1757-1764.

Nedashkovskaya, O. I., Kim, S. B., Kwon, K. K., Shin, D. S., Luo, X., Kim, S.-J. \& Mikhailov, V. V. (2007). Proposal of Algoriphagus vanfongensis sp. nov., transfer of members of the genera Hongiella Yi and Chun 2004 emend. Nedashkovskaya et al. 2004 and Chimaereicella Tiago et al. 2006 to the genus Algoriphagus, and emended description of the genus Algoriphagus Bowman et al. 2003 emend. Nedashkovskaya et al. 2004. Int J Syst Evol Microbiol 57, 19881994.

Niemann, S., Pühler, A., Tichy, H. V., Simon, R. \& Selbitschka, W. (1997). Evaluation of the resolving power of three different DNA fingerprinting methods to discriminate among isolates of a natural Rhizobium meliloti population. J Appl Microbiol 82, 477-484.

Park, S., Kang, S.-J., Oh, K.-H., Oh, T.-K. \& Yoon, J.-H. (2010). Algoriphagus lutimaris sp. nov., isolated from a tidal flat sediment. Int J Syst Evol Microbiol 60, 200-204.

Reichenbach, H. (1989). Order I. Cytophagales Leadbetter 1974. In Bergey's Manual of Systematic Bacteriology, vol. 3, pp. 2011-2013. Edited by J. T. Staley, M. P. Bryant, N. Pfennig \& J. G. Holt. Baltimore: Williams \& Wilkins.

Tamura, K., Dudley, J., Nei, M. \& Kumar, S. (2007). MEGA4: molecular evolutionary genetics analysis (MEGA) software version 4.0. Mol Biol Evol 24, 1596-1599.

Thompson, J. D., Gibson, T. J., Plewniak, F., Jeanmougin, F. \& Higgins, D. G. (1997). The CLUSTAL_X windows interface: flexible strategies for multiple sequence alignment aided by quality analysis tools. Nucleic Acids Res 25, 4876-4882.

Tiago, I., Mendes, V., Pires, C., Morais, P. V. \& Veríssimo, A. (2006). Chimaereicella alkaliphila gen. nov., sp. nov., a Gram-negative 
alkaliphilic bacterium isolated from a nonsaline alkaline groundwater. Syst Appl Microbiol 29, 100-108.

Tindall, B. J., Sikorski, J., Smibert, R. M. \& Krieg, N. R. (2007) Phenotypic characterization and the principles of comparative systematics. In Methods for General and Molecular Microbiology, pp. 330-393. Edited by C. A. Reddy, T. J. Beveridge, J. A. Breznak, G. Marzluf, T. M. Schmidt \& L. R. Snyder. Washington, DC: American Society for Microbiology.

Van Trappen, S., Vandecandelaere, I., Mergaert, J. \& Swings, J. (2004). Algoriphagus antarcticus sp. nov., a novel psychrophile from microbial mats in Antarctic lakes. Int J Syst Evol Microbiol 54, 1969-1973.

Xie, C.-H. \& Yokota, A. (2003). Phylogenetic analyses of Lampropedia hyalina based on the 16S rRNA gene sequence. J Gen Appl Microbiol 49, 345-349.
Yi, H. \& Chun, J. (2004). Hongiella mannitolivorans gen. nov., sp. nov., Hongiella halophila sp. nov. and Hongiella ornithinivorans sp. nov., isolated from tidal flat sediment. Int J Syst Evol Microbiol 54, 157162.

Yoon, J.-H., Yeo, S.-H. \& Oh, T.-K. (2004). Hongiella marincola sp. nov., isolated from sea water of the East Sea in Korea. Int J Syst Evol Microbiol 54, 1845-1848.

Yoon, J.-H., Lee, M.-H., Kang, S.-J. \& Oh, T.-K. (2006). Algoriphagus terrigena sp. nov., isolated from soil. Int J Syst Evol Microbiol 56, 777780.

Young, C.-C., Lin, S.-Y., Arun, A. B., Shen, F.-T., Chen, W.-M., Rekha, P. D., Langer, S., Busse, H.-J., Wu, Y.-H. \& Kämpfer, P. (2009). Algoriphagus olei sp. nov., isolated from oil-contaminated soil. Int $J$ Syst Evol Microbiol 59, 2909-2915. 